\title{
Degranulated Acidophils as a Possible Original Source of "Thyroidectomy Cells" in the Rat Hypophysis
}

\author{
FuJio YOSHIMURA, KanjI HARUMIYA, Hiroko YACHI, TsUYOSHI SOJI \\ AND Masataka YOKOYAMA
}

Department of Anatomy, Jikei University School of Medicine, Minato-ku, Tokyo

\begin{abstract}
Synopsis
The original source of thyroidectomy cells (TX-cells) in rats was investigated electron microscopically. Thyrotrophs did not respond so definitely to thyroidectomy as gonadotrophs did to castration. In thyrotrophs, changes in terms of hyperplasia, hypertrophy and de- or hypergranulation were not manifested. There was no evidence that TX-cells belonged to hyperactive thyrotrophs. The course of transformation from the degranulated acidophils to TX-cells was clearly demonstrated in sequence in this study. Hypertrophy, deformation of the cell, expansion of cisternae, occurrence of intracisternal granules and enlargement of the Golgi-ring, these were manifestations of the developmental process of degranulated acidophils into TX-cells. The other process of transformation of acidophils into TX-cells seemed related to the gradual dilation of ER without discharging their large granules completely. During the chronic phase of thyroidectomy, the anterior pituitaries were filled with TX-cells and their precursors. High vesiculation could be considered as an intrinsic biological reaction which is commonly seen in most of hypophyseal cells during thyroxine deficiency. It was, therefore, suggested that degranulated or slightly granulated acidophils might be predominantly the original sources of TX-cells. Thus, the acidophil theory has been firmly established as to the genesis of TX-cells. We, at the same time, wanted to open up a possibility that some TX-cells might arise from immature basophils, but the valid evidence was not produced in this study. It was verified electron microscopically that the fully developed round TX-cells seemingly like signet-ring-typed castration cells were quite different from genuine castration cells, although both cells had the same staining properties and light microscopical characteristics. However, a number of immature gonadotrophs came into being during the chronic phase of thyroidectomy.
\end{abstract}

There have been three conflicting opinions as to the genesis of thyroidectomy cells. First comes the orthodox theory that they originate from thyrotrophs which are responsible for the secretion of TSH. This theory was confirmed by Purves and Griesbach (1956) and by Dhom and Tietze (1962). More recently it has been definitely re-confirmed through immunochemical investigations by the use of anti-TSH (Baker and $\mathrm{Yu}, 1971$ ), through the high resolution radioautography with tritiated thymidine (Stratmann et al., 1972) and through the

Received for publication March 10, 1973. experiments of TSH rebound phenomenon in thyrotrophs (Rosa and D'Angelo, 1972). The second theory is the chromophobe theory proposed by Payne (1957), Peter and Halmi (1961), Applington (1962), Ueda and Mori (1968), Mastro et al. (1969a, b), Yoshimura and Ishikawa (1969) and Goluboff et al. (1970). This theory is based on the idea that thyroidectomy cells (TX-cells) are derived from chromophobes which are regarded as undifferentiated or stem cells of adenohypophysis. The above authors believe that TX-cells originate from chromophobes and think that all TX-cells do not always develop from 
thyrotrophs.

The third is a presumptive idea of acidophil origin. There have been no solid morphological evidences to corroborate this idea. The origination of TX-cells from acidophils was assumed, for the first time, in newts by Dent (1961) upon the histological observation. By a quantitative estimation of various cell types on electron microsgraphs of the pituitary in thyroidectomized rats, Dingeman (1969) recently found a rapid loss of LTH, LH and GH cells and suggested the development of TXcells from these three types of cells respectively. It is well known that thyroidectomy induces an apparent decrease in number of acidophils resulting in disappearance on the level of light microscopy and a marked reduction of the pituitary GH content. No investigators have conceived that the loss of acidophils may be specifically related to the development of TX-cells. According to the electron microscopical investigation of Harumiya (1972), one of the present authors, on the fate of acidophils following thyroidectomy, large acidophil granules (about $350 \mathrm{~m} \mu$ in diameter) were lost in the initial phase and small ones $(130 \mathrm{~m} \mu)$ were gradually discharged in a chronic phase and sequently agranular acidophils were induced. The destination of degranulated acidophils was not, however, determined by Harumiya.

In this investigation, we shall challenge the orthodox theory of thyrotroph origin, and attempt to adduce evidences for the direct transformation of degranulated acidophils to TX-cells in order to establish definitely the acidophil theory.

\section{Materials and Methods}

Male Wistar-Imamichi rats, 45 days of age, were thyroparathyroidectomized and sacrificed 3, 5, 7, 15, 30,50 and 200 days respectively after the operation. Five intact rats, 60 days of age, were used as the control. At autopsy, the thyroid region was grossly examined in detail as to whether or not a piece of the thyroid tissue remained over the thyroidectomy to be a compensatory hypertrophy. The animals with a microscopic remnant of the thyroid tissue were excluded from the experiment. The animals successfully thyroidectomized was 5 in number in each group. Two of the thyroid-ectomized rats in each group were injected with $500 \mathrm{Ci}$ of ${ }^{131} \mathrm{I}$ in order to destroy the remaining thyroid tissues completely. After operation, the animals were placed ad libitum on $\mathrm{CE}_{2}$ diet obtained from the Central Experimental Animal Laboratory (Japan) and on water. They were maintained at room temperature $25^{\circ} \mathrm{C}$. Although the diet was not supplemented with $\mathrm{Ca}$, no tetanic symptom was observed in all the operated animals.

For electron microscopy, pituitary tissues were fixed in $2 \%$ osmic acid in a pH 7.4 phosphate buffer solution (Millonig, 1961) or in a $\mathrm{pH} 7.4$ veronal acetate buffer solution for $2 \mathrm{hr}$. Some tissues were fixed in a $3 \%$ glutaraldehyde phosphate buffer at $\mathrm{pH} 7.4$ for $2 \mathrm{hr}$ and fixed again in a buffered $2 \%$ osmic acid solution for $2 \mathrm{hr}$. Following fixation, the tissues were dehydrated in an increasing percentage of cold ethanol, treated with prophylenoxyde for $10 \mathrm{~min}$, infiltrated, and embedded with Luft's epoxy resin 812 . Thin sections were made with the PorterBlum ultratome, mounted on copper grids, and stained with a saturated aquzous solution of uranyl acetate and then with the lead solution of Reynalds (1963). The sections were examined with a JEM 7A type electron microscope.

For light microscopy, other sections of $2.0 \mu$ in thickness were transferred into a drop of water on clean slides and were flattened and dried by placing the slides on a hot plate at $60^{\circ} \mathrm{C}$ for $5 \mathrm{hr}$. The removal of epoxy resin from the sections before staining was performed by the method described by Imai et al. (1968). After removal of the embedding media, some of the sections were stained with periodic acid-Schiff's reagent with the counterstain of iron hematoxylin of Heidenhain. The rest of the sections were stained simply with $0.5 \%$ aldehyde thionine solution (Paget and Eccleston, 1957).

\section{Observations}

\section{Thyrotrophs and immature basophils under normal and experimental conditions \\ The definition of thyrotrophs on electron micrographs has been controversial among many investigators. From our observations of the normal control rats their characteristic features can be summarized as follows. They are either angular or polyhedral in shape, and contain in their cytoplasm a number of small}


dense granules, $130-150 \mathrm{~m} \mu$ in maximal diameter. Granularity varies with individual thyrotrophs. There are some thyrotrophs which contain small granules alined in a row in adjacent to the cytomembrane, and some thyrotrophs in which small granules are scattering in various areas and/or accumulating in certain areas. The endoplasmic reticula (ER) are usually canalicular; mitochondria are generally slender and more or less elongated, and their cross-sections are always smaller than those of acidophils.

For the evaluation of the experimental results, thyrotrophs were identified according to the above criteria. Although it was expected that thyrotrophs multiplied and exerted hyperactivity following thyroidectomy due to the negative feedback mechanism, they appeared only infrequently in the pituitaries. Their fine structure was not remarkably different from that of the control (Figs. 7 and 11). Beta granules were uniformly found at various areas, manifesting no predilection for site. The present experiment demonstrated that the identifiable thyrotrophs were not affected or hyperactive. It seemed impossible, however, to find the accurate quantitative changes of thyrotrophs on the electron micrographs. Although thyrotrophs were frequently found in the early phase and interphase of thyroidectomy, they were seldom found in the chronic phase. When the same samples for electron microscopy were stained with aldehyde thionine after removal of epoxy resin, the polygonal cells stained dark blue homogenously were scattered sparsely throughout the adenohypophysis in the early phase and interphase of thyroidectomy (Fig. 3 ). They were nothing but thyrotrophs which were not hypertrophic or hyperplastic. The existence of intermediary cells between thyrotrophs and TX-cells was not confirmed.

The cells shown in Figure 8 were identified with intermediate cells between chromophobes and basophils. The name, intermediate cell, was first given by Yoshimura et al. (1969) and Ishikawa (1969), who regarded them as imma- ture basophils. They would exist in a cluster in different places and always take a polyhedral shape. Some of them were connected with neighbouring cells with their thin processes, and many small $\beta$-granules 100 to $150 \mathrm{~m} \mu$ in maximal diameter were scattered in the early phase. However, this type of immature basophils was not frequently detected toward the end of the early phase. It is worthy of mentioning that thyrotrophs and immature basophils do not accumulate granules or cisternae of ER in the later phase of thyroidectomy. Although we had no evidence to show that the enlarged immature basophils became TX-cells directly, its transformation could not still be denied.

\section{Changes in Gonadotrophs}

As has been established, these so-called FSHgonadotrophs in the normal male adult rats always show an ellipsoid or a spherical shape; ER are definitely dilated and anastomosed to form a network. Their cross-sections sometimes look like independent cisternae of irregular shape. The narrow ground matrix of cytoplasm penetrated by tortuous cisternae includes numerous middle-sized granules of 200 to $250 \mathrm{~m} \mu$ in diameter. In the present observations, no drastic change took place in gonadotrophs following thyroidectomy. But in the early phase (5, 7 and 15 days) some gonadotrophs tended to be dysfunctioning and ER were further dilated and the nuclear membrane was pressed to form irregular surfaces (Fig. 9). The cell-bodies generally atrophied to be high in electron density without discharging granules. Despite such features of dysfunction or retrogression in the early phase, gonadotrophs did not die out or disappear but their retrogression tended to be alleviated. Upon the epon sections stained with PAS-iron hematoxylin, such difference was not seen between TX-cells and gonadotrophs. Figure 2 shows enlarged round TXcells ( 30 to $50 \mu$ in diameter) in 15 days after thyroidectomy, and Figure 6 shows two spherical intact gonadotrophs rather small in size $(20-35 \mu)$ at the same interval. The size 

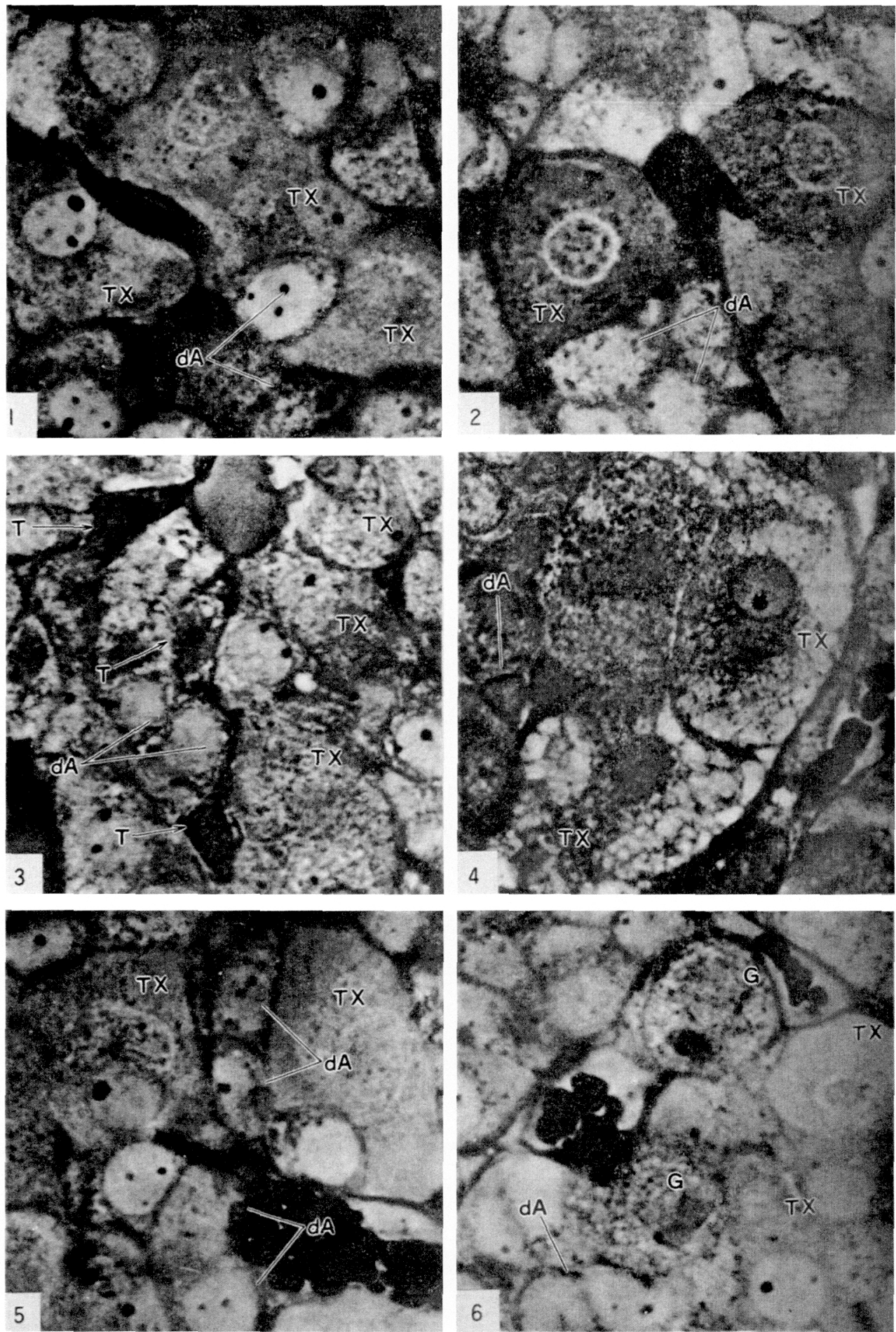

Fig. 1-6. All the photomicrographs were taken of thin sections (2 $\mu$ in thickness) of the 
pituitary tissues embedded in epoxy resin. These sections, after removal of epoxy resin, were stained with PAS-iron hematoxylin (Figs. 1, 2, 5, 6) and with aldehyde thionine (Figs. 3 and 4). All the photographs, approximately $1200 \times$

Fig. 1. Seven days after thyroidectomy. The extraordinarily hypertrophied polygonal cells are stained diffusively with PAS. They are clearly identified with TX-cells (TX) by prominent Golgi-rings. Loss of acidophils from the adenohypophysis is remarkable. dA, degranulated acidophils.

Fig. 2. Fifteen days after thyroidectomy. Two big round TX-cells located centrally are stained intensively with PAS. Their picture is identical with that of the hypertrophied, fine vesiculated gonadotrophs having the typical Golgi-ring like castration cells.

Fig. 3. Seven days after thyroidectomy. Three typical, irregularly shaped thyrotrophs (T), small in size, are stained heavily and homogeneously with thionine. Many vesiculated TX-cells of different sizes are seen intermingling. There remain sometimes a few degranulated acidophils (dA); T-granules are sometimes found stained with thionine in the enlarged vesiculated TX-cells.

Fig. 4. Fifteen days after thyroidectomy. TX-cells have attained a maximum enlargement and contained expanded vacuoles corresponding with ER. These giant cells are synonymous with the round vesiculated TX-cells identifiable with an electron microscope. Note the T-granules stained strongly with thionine and accumulated in TX-cells.

Fig. 5. Seven days after thyroidectomy. Vesiculation and expansion of ER are not clearly seen in large TX-cells. It is noteworthy that there are no acidophils keeping $\alpha$ granules in their cell-bodies.

Fig. 6. Fifteen days after thyroidectomy. Gonadotrophs $(G)$ which are always smaller than round vesiculated TX-cells (TX) tend to increase in number in the subchronic phase of thyroidectomy. As described below, these gonadotrophs have been identified electron microscopically with genuine gonadotrophs, but not with TX-cells (see Fig. 10).

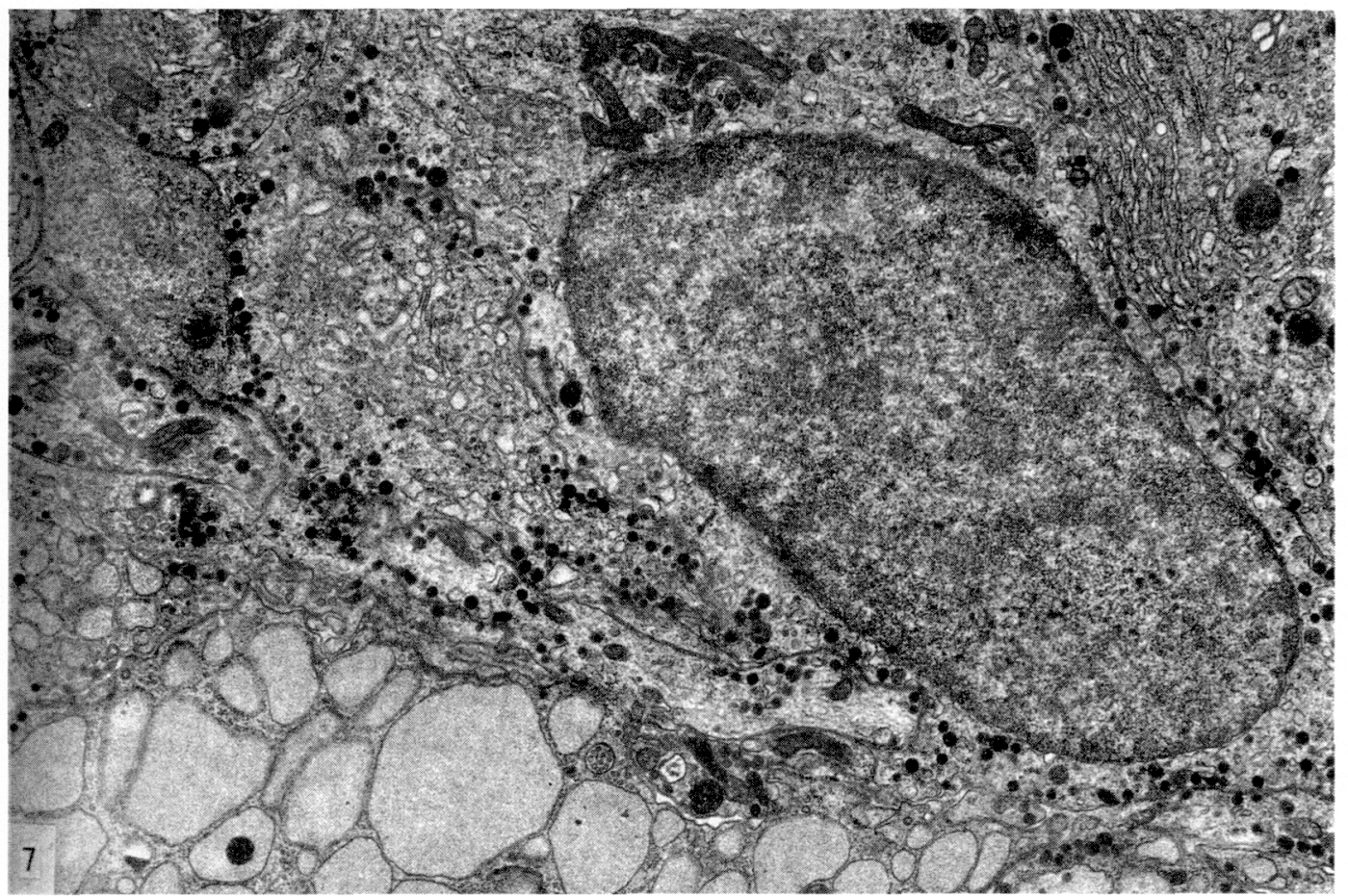

Fig. 7. A thyrotroph, 5 days after thyroidectomy. It is not appreciably different from intact thyrotroph which is characterized by elongated small mitochondria and special distribution of $\beta$-granules in adjacent to the plasmamembrane. $9500 \times$. 


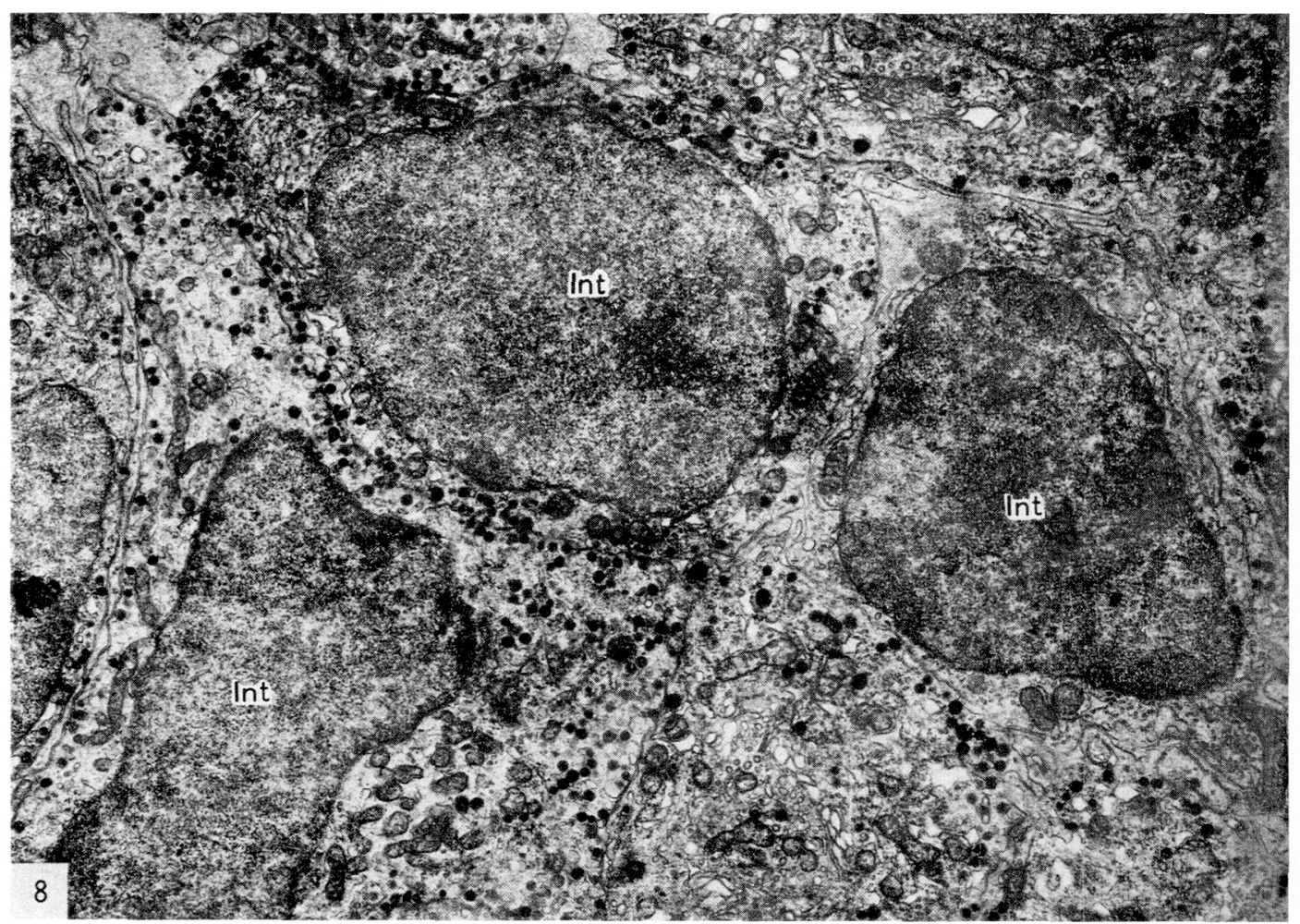

Fig. 8. Intermediate cells between chromophobes and basophils, 7 days after thyroidectomy. Chromophobes in a clustsr gradually assume fine structural characteristics of immature basophils. In these intermediate cells (Int) newly produced $\beta$-granules accumulated particularly in the peripheral areas in the course of cell differentiation. $7800 \times$.

of TX-cells was about twice as large as normal gonadotrophs (see Fig. 2 and Fig. 6); the former is characterized by the occurrence of big T-granules stained heavily with PAS-iron hematoxylin and aldehyde thionine respectively. These kinds of round cells resemble each other in the presence of prominent Golgi-rings and the positive stain with PAS. On the other hand, polygonal TX-cells are extraordinarily large in which the Golgi-ring is enlarged and vacuolization takes place progressively (Figs. 1, 4, 5).

However, gonadotrophs and round TXcells can readily be distinguished electron microscopically by their fine structures. Round gonadotrophs easily detectable in $14,50,60,90$ and 200 days after thyroidectomy
(Fig. 10) contained many dilated cisternae, in which fine granulated materials were concentrated. When the electron density of these materials became high they simulated exceedingly large secretory granules; their ground matrix were laden with $\beta$-granules. Thus, gonadotrophs of this kind were commonly observed in the pituitaries of immature male rats. Gonadotrophs of this immature type seemed to come up newly in the chronic phase of thyroidectomy.

\section{Conversion of degranulated acidophils into $T X$-cells}

The present observation on the degranulating process of acidophils fully corresponded with the findings of Harumiya (1972). In 


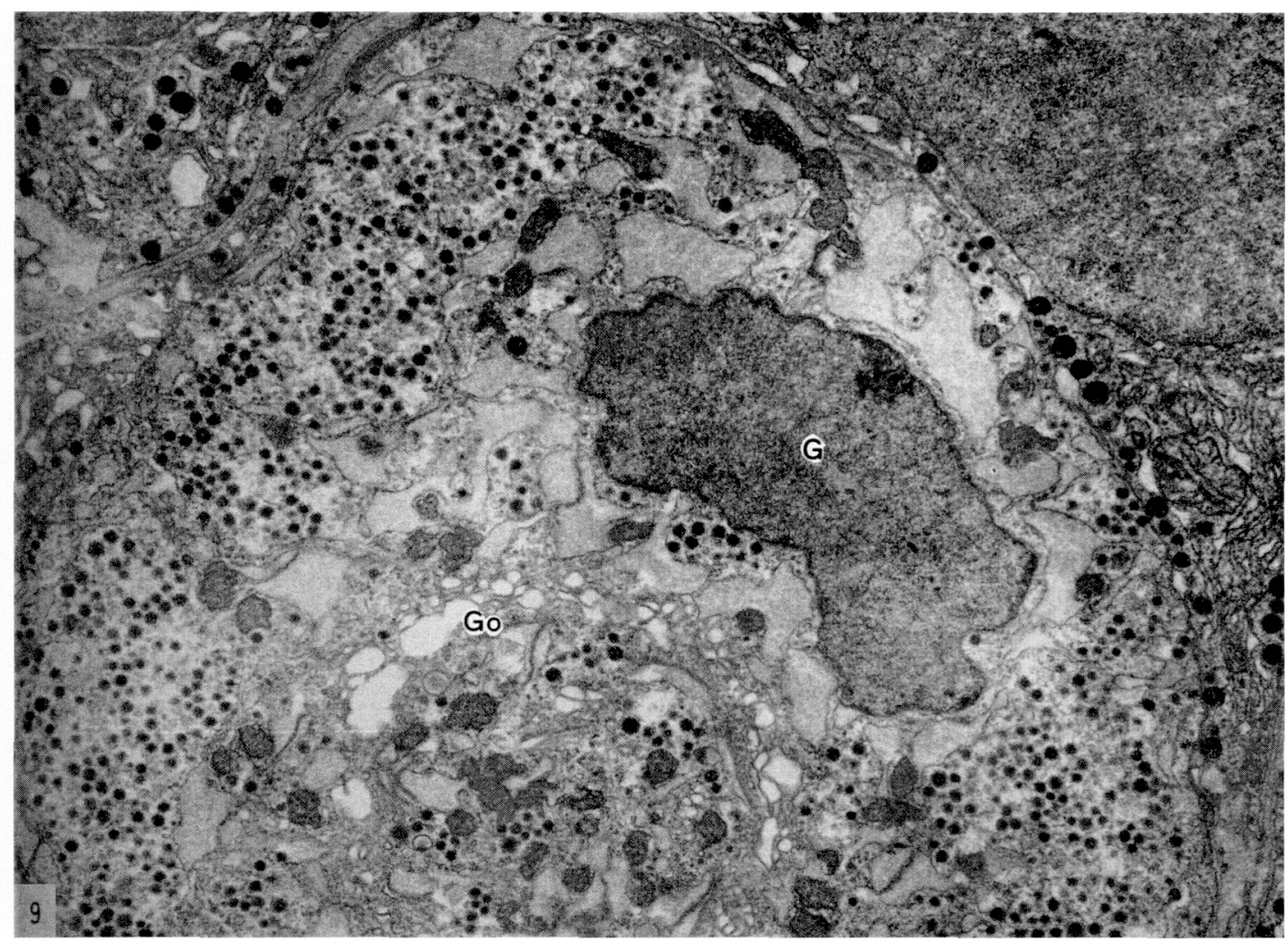

Fig. 9. A gonadotroph which is suspected to be dysfunctioning, 15 days after thyroidectomy. Its ground matrix packed with $\beta$-granules (200 to $250 \mathrm{~m} \mu$ in diameter) is penetrated by anastomosing cisternae of irregular shape. The nucleus is pressed by the adherent exanded ER. Go, Golgi-ring $7800 \times$.

connection with the fate of degranulated acidophils, a series of pictures of transformation from acidophils to TX-cells are demonstrated here in this study as follows: In Figure 11 there are observed agranular acidophils whose shapes are ellipsoid or polygonal. Seven or 15 days after thyroidectomy, some of degranulated acidophils lost granules of either size. The canalicular ER distributed in parallel tended to be gradually dilated. Instead of granules, lysosomal bodies were sometimes deposited (Fig. 12). Occasional occurrence of the multivesicular bodies may indicate their origination from acidophils. In a degranulated acidophil shown in Figure 12 there were a few small granules $130 \mathrm{~m} \mu$ in maximal diameter along the cytomembrane. The presence of Jysosomes and large mitocondria may be a criterion to identify the revelant cells with acidophils (compare Fig. 12 with Fig. 7). Because of this difference, a cell in Figure 12 was thought to belong to degranulated acidophil and not to thyrotroph. In this cell the canalicular ER were expanded and the Golgi lamelles formed an indistinctive circle. However, the question remains unsettled until it is clarified whether agranular cells come from degranulated acidophils or from hypertrophied immature basophils deprived of their own $\beta$-granules. An agranular, enlarged cell shown in Figure 13 became 1.5 to 2.0 times as large as the starting agranular cells seen in Figure 12. Cisternae began to develop and became large in size at the periphery of cell-body within 15 days (Fig. 13). In the Golgi area and in its vicinity a large number of small vesicles 


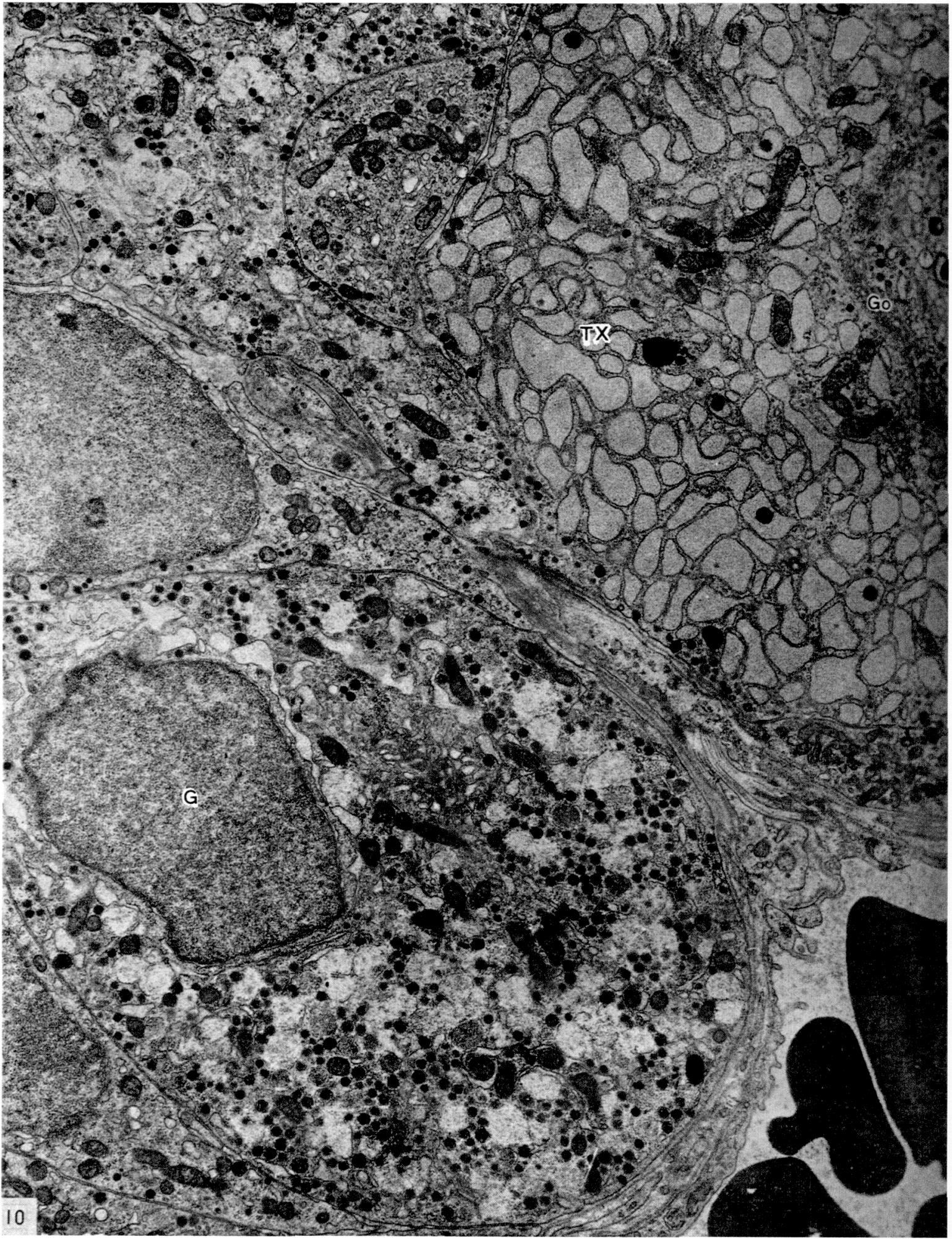




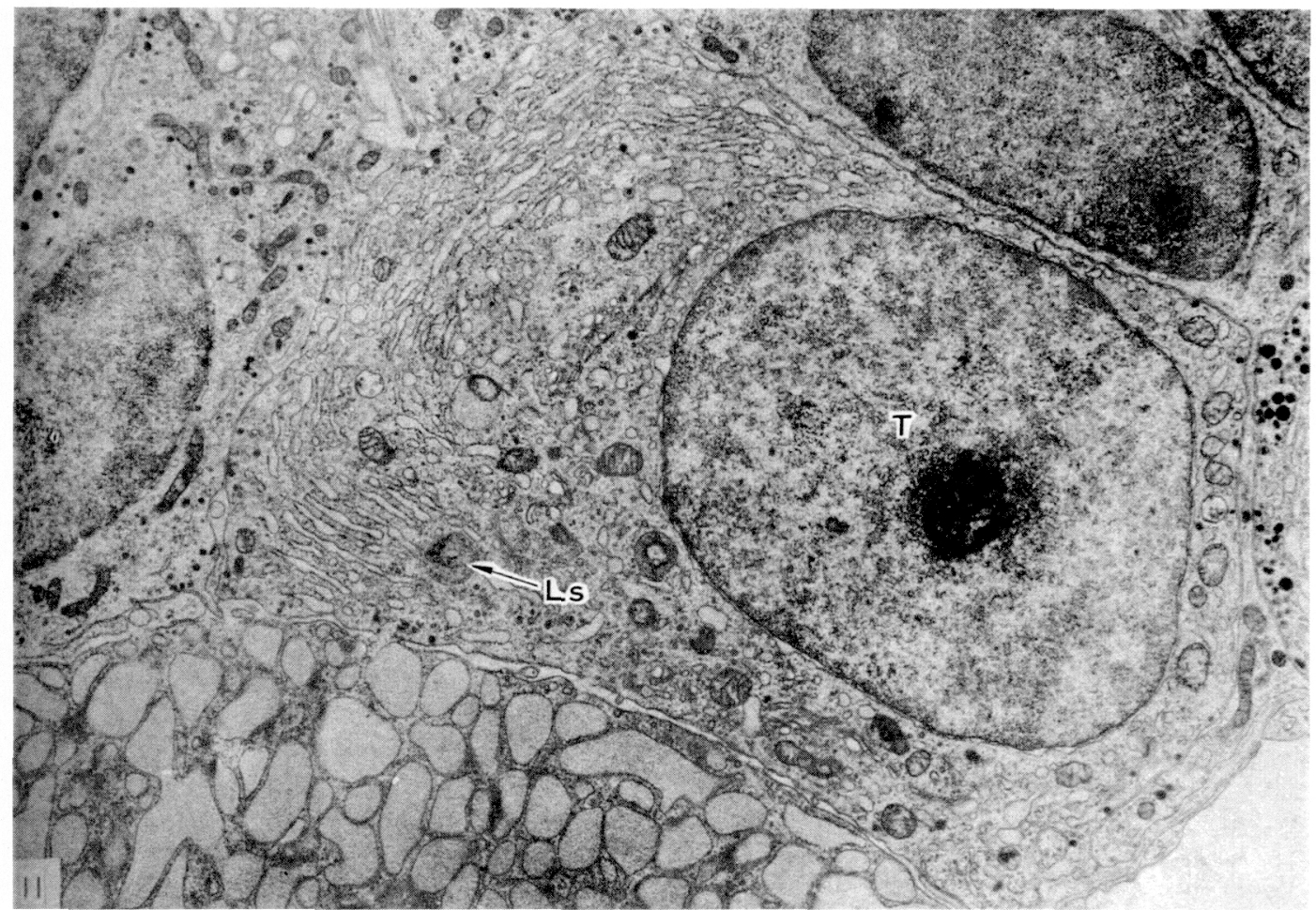

Fig. 11. An acidophil devoid of granules, 15 days after thyroidectomy. Many acidophils are completely deprived of their granules. The canalicular ER, densely distributed and running in parallel with each other, begin to dilate. Ls, lysosome; T, thyrotroph without signs of elaborated function. $7800 \times$.

were concentrated, but in other locations the canalicular ER were slightly dilated. Irregularly shaped, dense bodies, which had shown a tendency to congregate in the Golgi area, dispersed to the peripheral areas, and some of them were detected in the lumen of cisternae. They were identical with "intracisternal granules" or with "T-granules", which were readily distinguished through a light microscope. These granules lacking the limiting membrane were stained with PAS, aldehyde thionine as well as iron hematoxylin. In Figure 14 cisternae are fused one another to make a large cavity in the cell-body still keeping the distinctive Golgi-ring. This cell is presumably consistent with a large ellipsoid TXcell, which is identical with the cell illustrated light microscopically in Figure 4. There is a remarkable increase of $\mathrm{T}$-granules involved by cisternae. This makes a piquant contrast between TX-cells and genuine gonadotrophs. Figure 10 facilitates fine structural comparison between a gonadotroph and a round TX-cell. An old TX-cell in the chronic phase is shown in Figure 15, whose cytoplasm is divided into several compartments by intracel-

Fig. 10. A gonadotroph in comparison with a round vesiculated thyroidectomy cell, 60 days after thyroidectomy. Fine structures of these two cells are quite different. A gonadotroph $(G)$ contains many dilated round cisternae in which fine granulated material is concentrated. On the other hand TX-cell (TX) is full of anastomosing cisternae of irregular shape. Intracisternal granules are about to appear. The light microscopical findings as to G and TX shown in Figure 6 should be noted. $7800 \times$. 

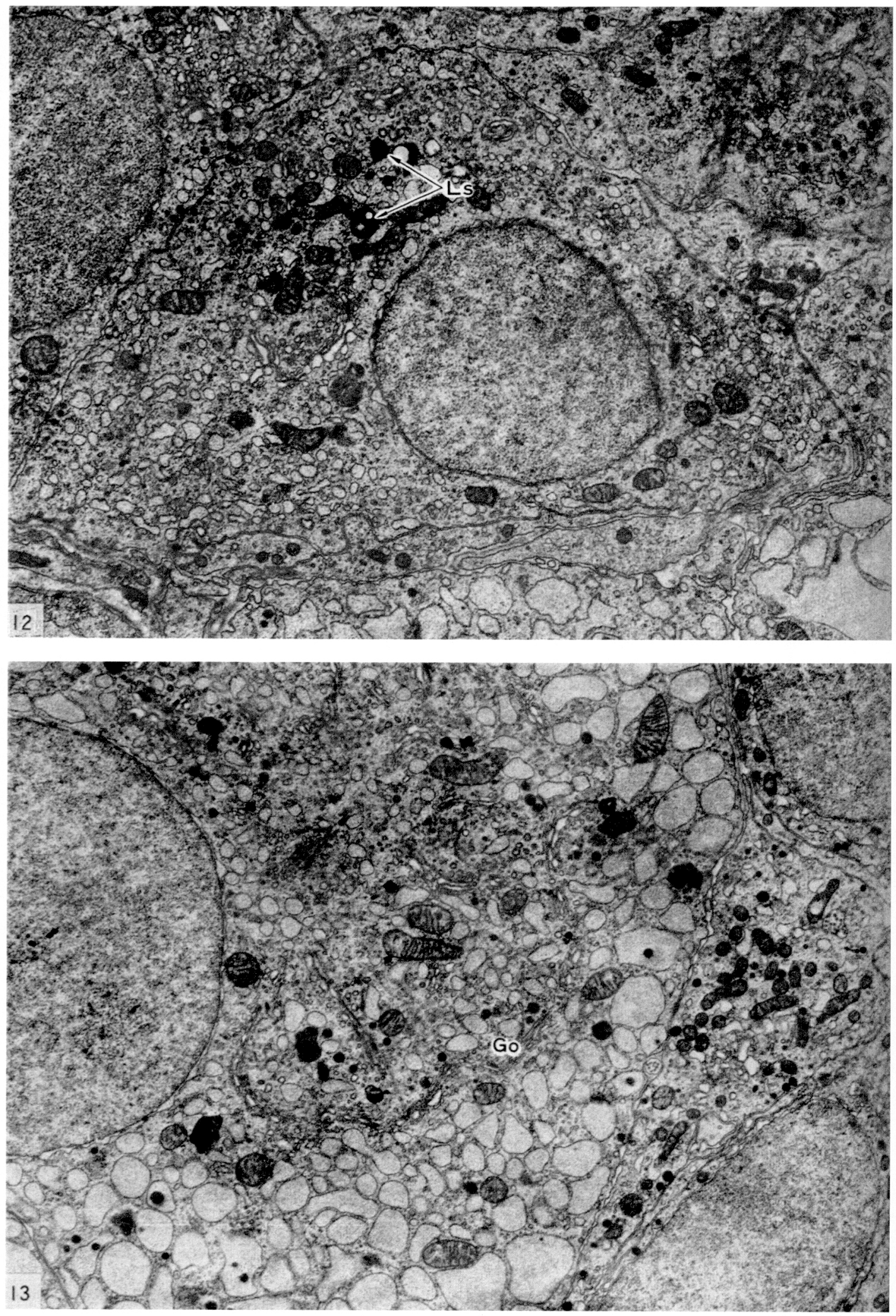


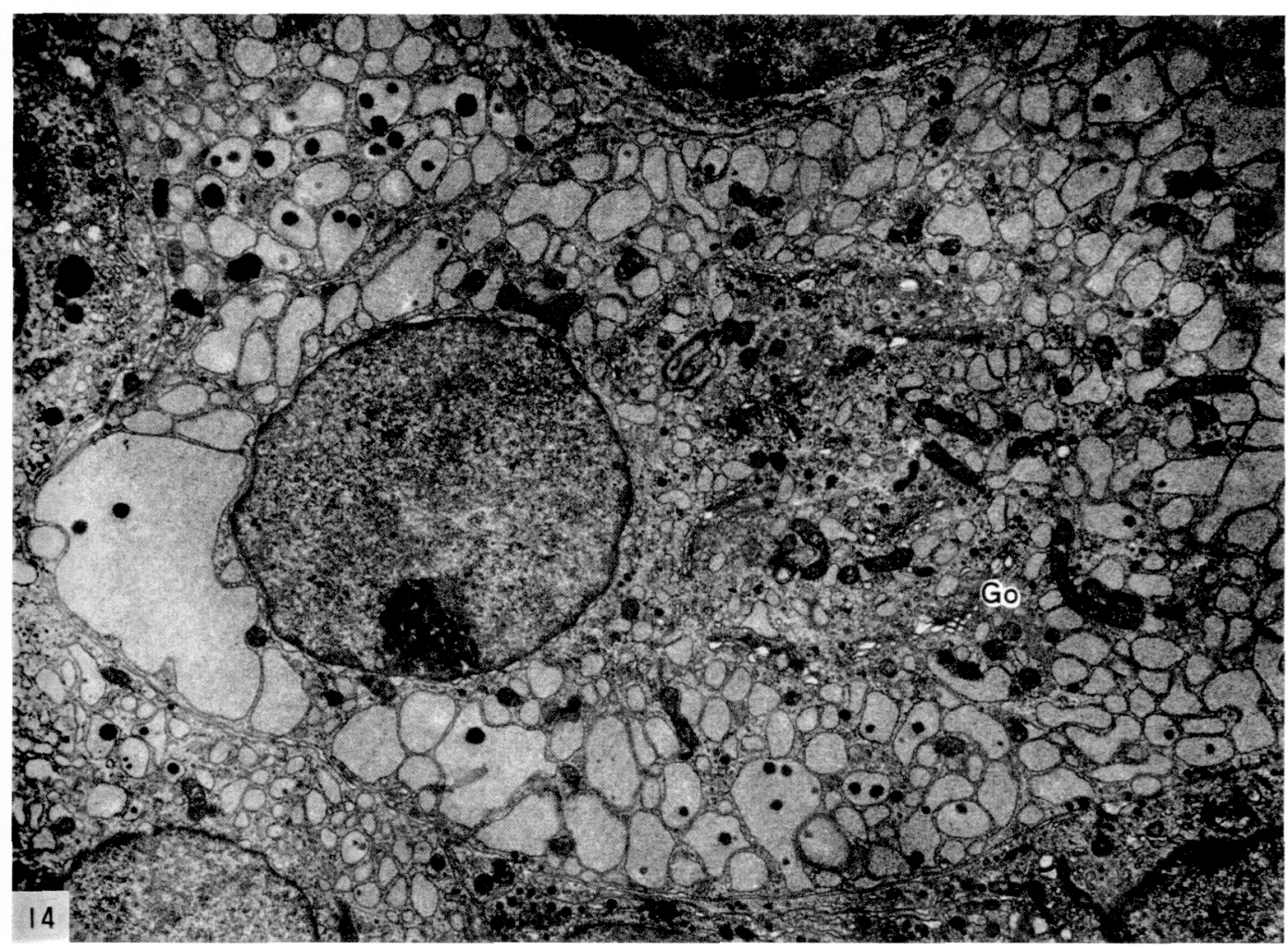

Fig. 14. Initial formation of a TX-cell, 15 days after thyroidectomy. In this ellipsoid TX-cell, the cisternae are fused to form a large cavity, in which intracisternal granules are often present. The prominent Golgi-ring $(\mathrm{Go})$ is preserved in the center. It should be remembered that the homogeneous substance in cisternae is stained weakly with PAS as already seen in Figures 1 and 5.6800 $x$.

lular septula. This cell resembles utterly a signet-ring cell which appears frequently during the chronic phase of castration. The cytological features of the typical signet-ring cells embracing large intracellular cavities filled with homogeneous materials are completely similar to those of castration cells except the intervention of intracisternal gran- ules (Fig. 10). From our above demonstration of the transitional pictures, the development of TX-cells from degranulated acidophils may be clear.

Another developmental process of TX-cells from acidophils will also be illustrated here. In some acidophils which retain a small number of large granules as early as 5 days after

Fig. 12. An agranular acidophil, 7 days after thyroidectomy. After considerable depletion of granules from the cell-body, this cell modifies its shape to polygonal. ER are dilated considerably. Ls, lysosome. $8500 \times$.

Fig. 13. Expansion of ER and formation of cisternae in an agranular acidophil, 15 days after thyroidedtomy. ER are particularly expanded in the peripheral area of the cellbody with consequent formation of cisternae. Large round vesicles are not associated with the Golgi area (Go), while many small ones occasionally containing the intracisternal granules are scattering in the vicinity of Golgi area, $8500 \times$. 

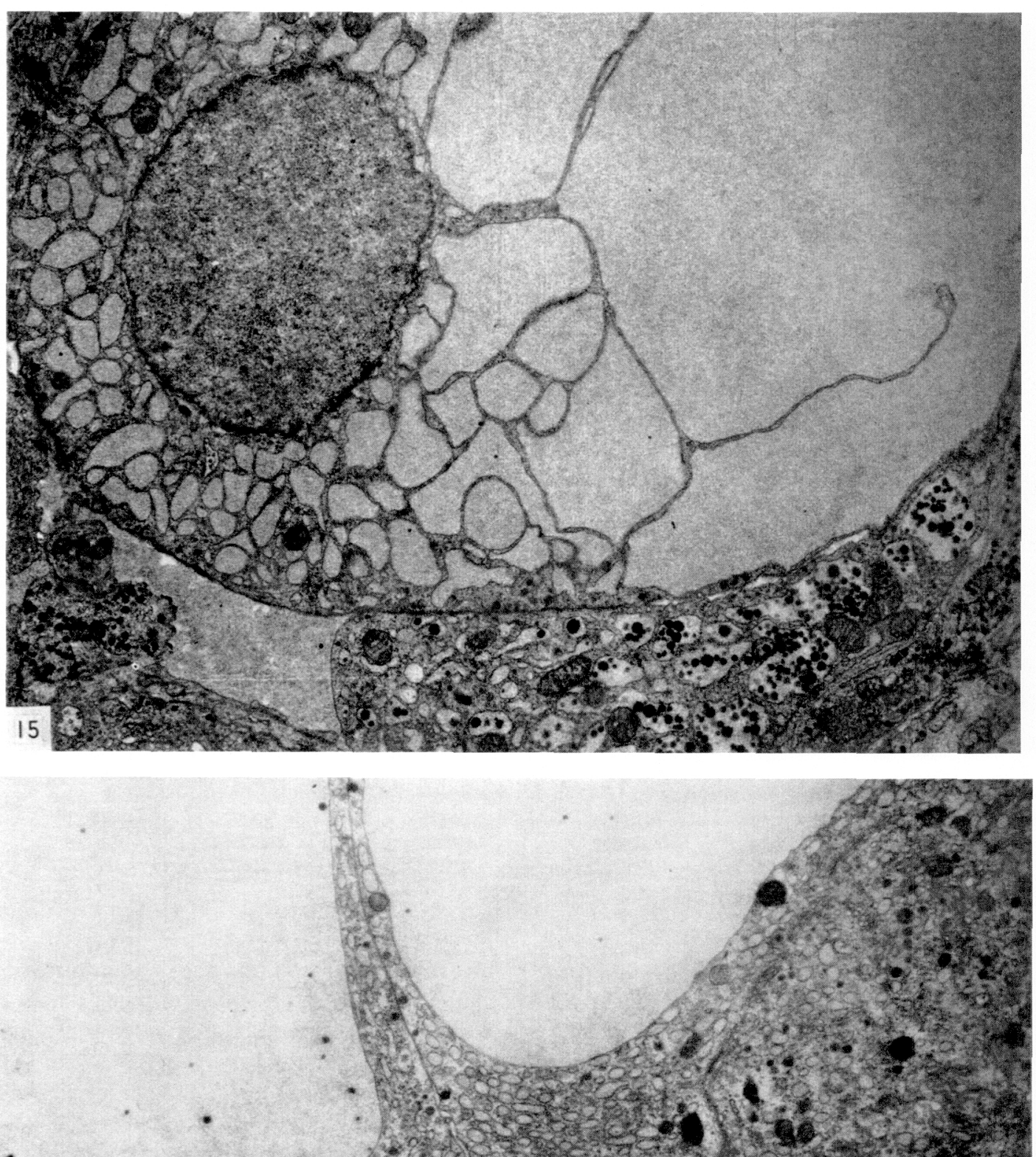
$30 \% 3$

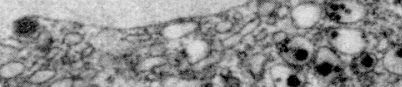

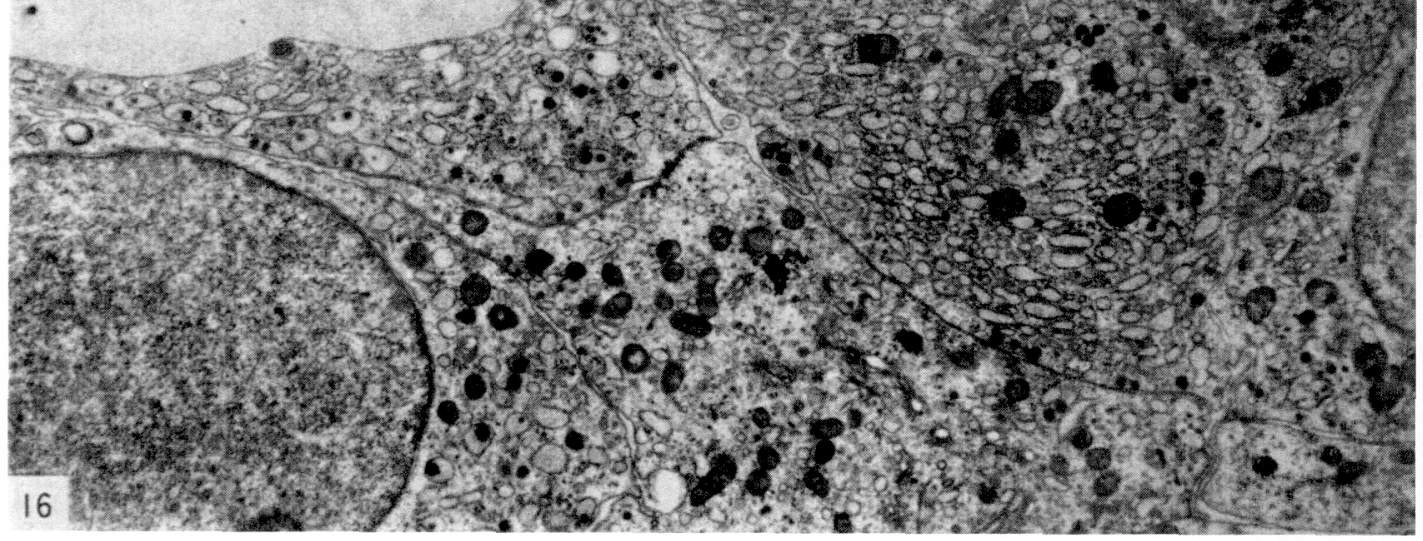




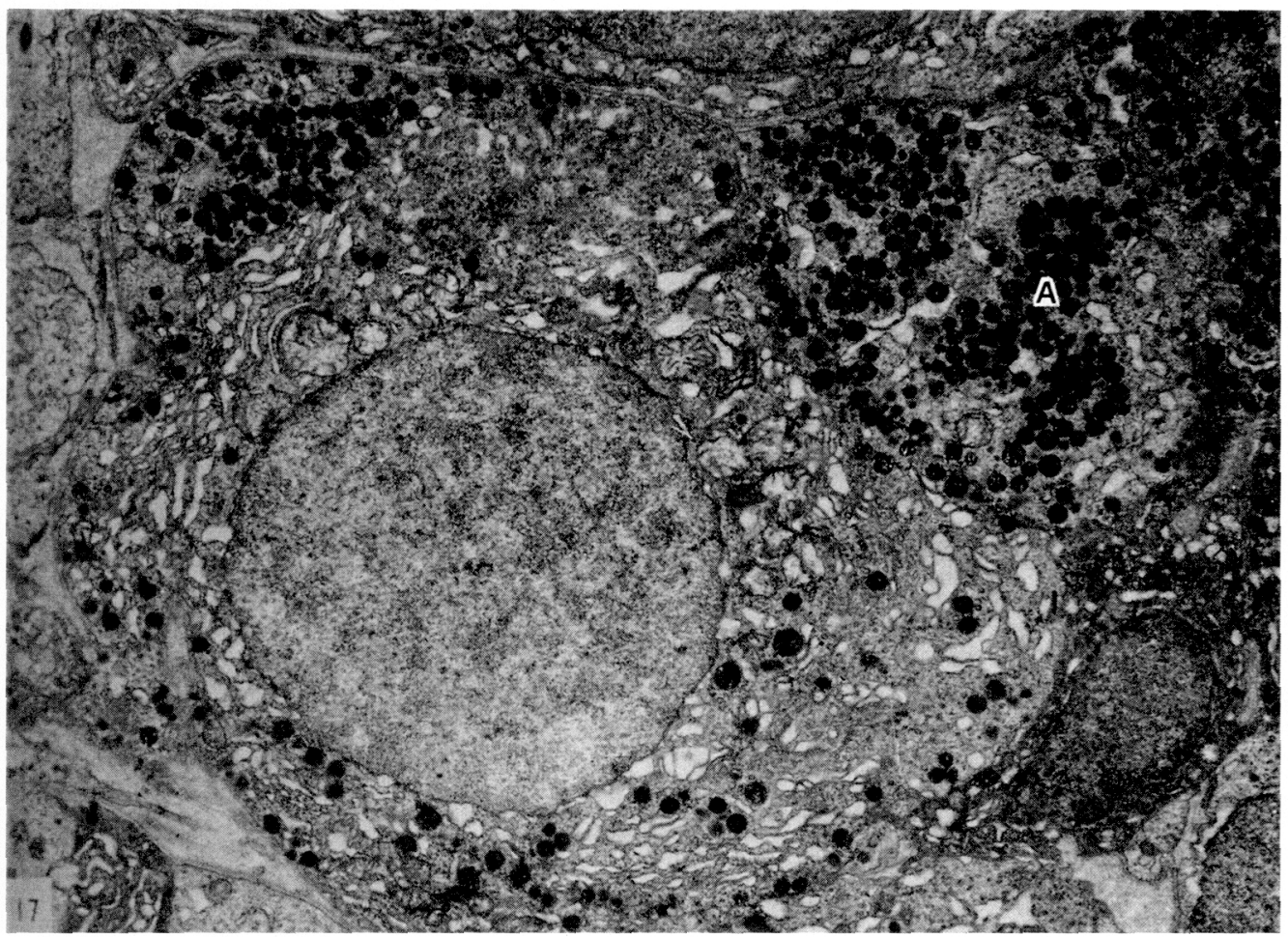

Fig. 17. An acidophil preserving a small number of large granules, 5 days after thyroid ectomy. The lamellar ER are dilated in this cell before depletion of their granules is accomplished. A, acidophil with large granules. $9500 x$.

thyroidectomy, the canalciular ER are dilated extensively (Fig. 17). Similarly, an acidophil shown in Figure 18 contains a large number of the expanded ER, in addition to a few remaining large granules in 5 days after thyroidectomy. In an acidophil which contains a few fine granules instead of the large ones (Fig. 19), the canalicular ER are more dilated and more densely distributed. In either way most acidophils are extensively vesiculated and provided with common features of TX-cells.

In summary, the present observation revealed that the ER in degranulated acidophils were mostly dilated to form a vesicular pattern during the interphase of thyroidectomy. Eventually, the cisternae dilated and fused

Fig. 15. So-called signet-ring cell, 50 days after thyroidectomy. Vesicles coalesce into a big cavity occupying a half of the cell-body, manifesting the aspect of signet-ring cell. But this cell is not a genuine castration cell but belongs to a kind of TX-cell. $6800 \times$.

Fig. 16. Two TX-cells of the typical signet-ring cell, type, 60 days after thyroidectomy. In the chronic phase, many TX-cells turn into typical signet-ring cells which present the identical picture with that of castration cells due to the long-term preservation of some materials in the big cavity. Electron-microscopically, it is possible to distinguish TX-cells from the genuine castration cells by the presence of intracisternal granules. $6800 \times$. 

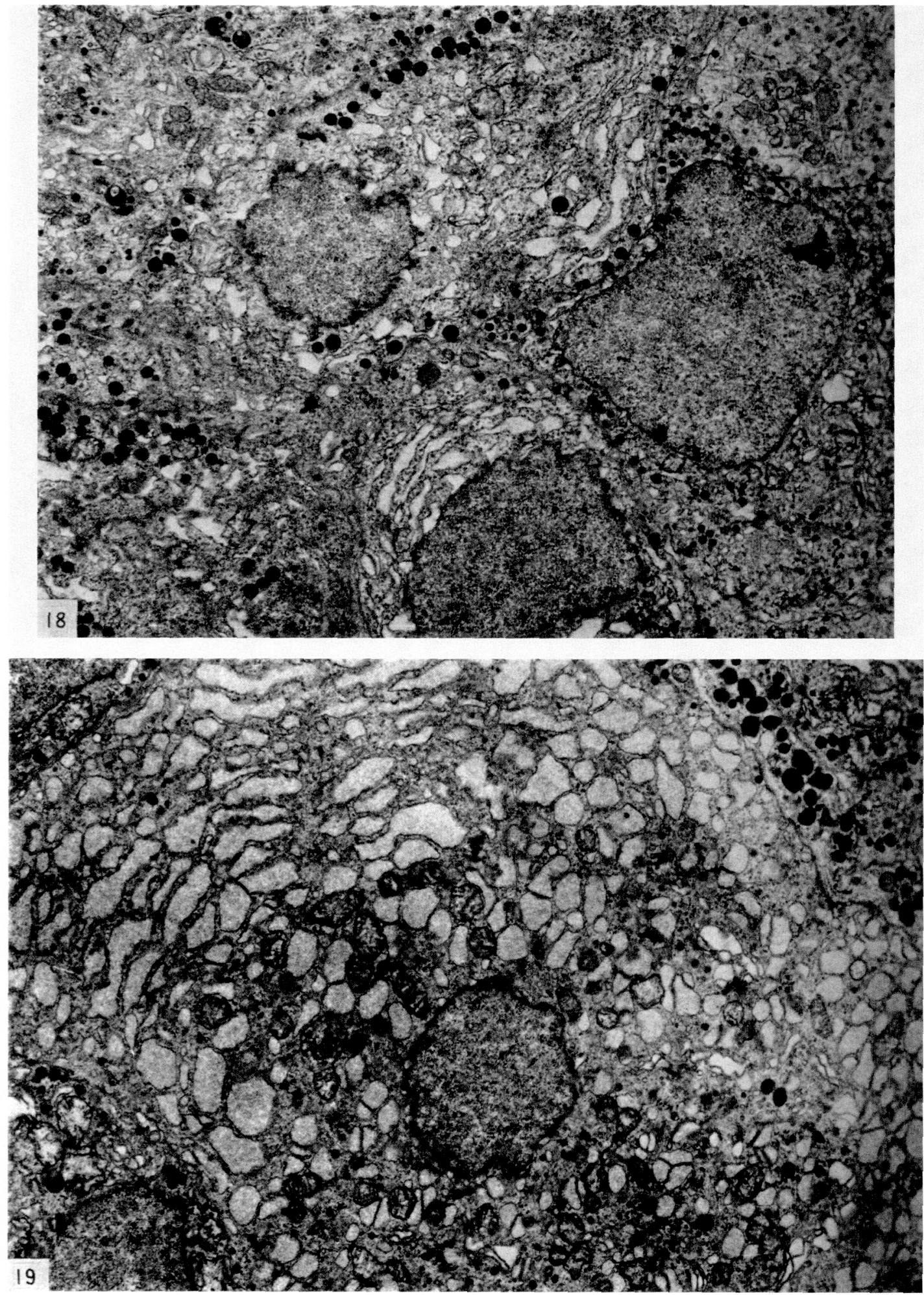


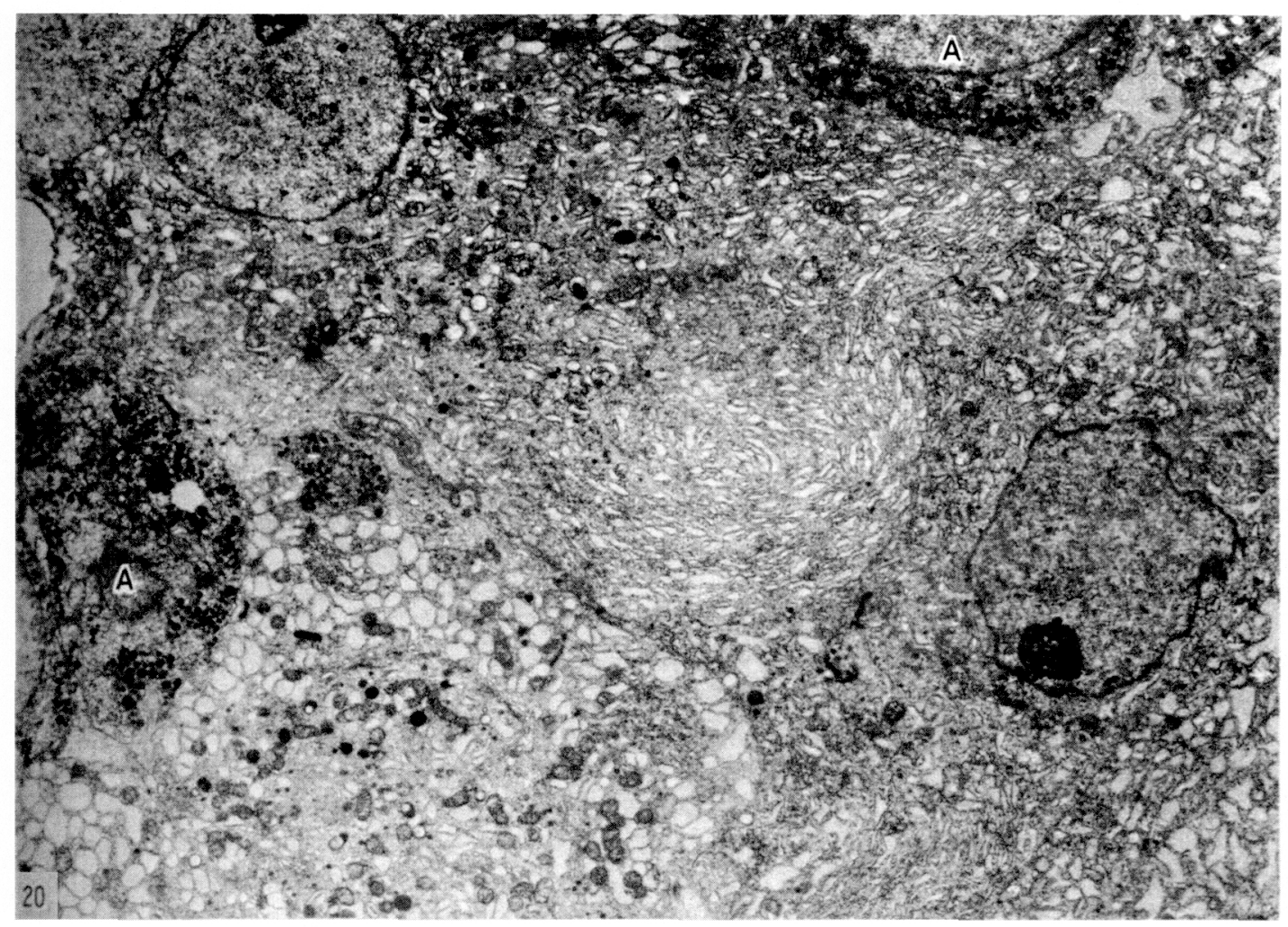

Fig. 20. Massive thyroidectomy cells occupying the anterior pituitary, 7 days after thyroidectomy. Most of constitutional cells of the anterior lobe are of vesiculated type. But the lamellar ER are dilated in varying degrees with individual cells. A, acidophil leaving numerous large granules. $4500 \times$.

were invaded by $\mathrm{T}$-granules. Thus, mature TX-cells developed and almost occupied the anterior pituitary together with their precursor cells. As is seen in Figure 20 of low magnification, dilation of $E R$ or vesiculation in the most adenohypophyseal cells.

Fig. 18. Remarkable dilation of the lamellar ER in degranulated acidophils, 5 days after thyroidectomy. These cells preserve a few large granules (300-350 $\mathrm{m} \mu$ in diameter), but no small ones $(130-150 \mathrm{~m} \mu)$. Extensive dilation of the lamellar ER presents evidence that these cells can transform into TX-cells. $9500 \ldots$.

Fig. 19. A TX-cell which may have originated from a vesiculated acidophil, 5 days after thyroidectomy. Larg granules are scarecely detectable, whereas small ones are detected occasionally. The appearance of vesiculation accounts clearly for the origination of TX-cells from acidophils. Small intracisternal granules begin to arise. $8700 \times$. 


\section{Discussion}

The population of thyrotrophs in the rat pituitaries constitutes only $0.87 \%$ of the total cell number, and decreases to $0.11 \%$ on the 30th day of thyroidectomy (Messier, 1966). As the administration of thyroxine to the thyroidectomized rats made the scanty thyrotrophs increase rapidly above normal, Messier thought that this increase was due to the quick transformation of thyrotrophs from chromophobes. Yoshimura and Ishikawa (1969) histometrically calculated the number of thyrotrophs following thyroidectomy upon the preparations stained with PAS-iron hematoxylin and aldehyde thionine-PAS-luxol fastblue respectively, and pointed out that the increase in number of thyrotrophs waned during a period between the 10th and 60th days of thyroidectomy and their largest population represented an increase by $5 \%$ on the 40th day. The pituitary TSH content diminished during the early phase of thyroidectomy and the reduced value continued for as long as 20 or 42 days after the operation (Mess, 1958; Contopoulos et al., 1958; Salomon, 1964). Also Panda and Turner (1967) displayed that the pituitary TSH content was reduced conspicuously from 68.26 to $34.90 \mathrm{mU} / \mathrm{mg}$ within 24 days, while the plasma TSH content increased to a maximal level within 10 days, irrespective of the spontaneous reduction to the normal level within 20 or 42 days. D'Angelo (1963) pointed out the long-term maintenance of the low pituitary TSH content by goitrogen treatment for 4 months.

In the present electron microscopical observation, there existed no evidence of accumulation of small $\beta$-granules about $130 \mathrm{~m} \mu$ in diameter in the identifiable thyrotrophs following thyroidectomy, and it was not observed that these granules were vigorously discharged. Judging from the accumulated data on the population of thyrotrophs and the pituitary and serum TSH content, many researchers believed that the thyrotroph was an only cell which responded to thyroidectomy. If thyrotroph was an only cell responsible for TSH secretion as claimed by Nakane (1971) with his immunochemical technique, $\beta$-granules must be carriers of TSH and released into the blood. However, in our electron microscopy the extrusion of $\beta$-granules was not perceptible. It was learned from this study that the reduction in number of $\beta$-granules was not necessarily in parallel with that in pituitary TSH content. Consideration upon the functional significance of the high serum and low pituitary TSH content following thyroidectomy leads to a speculation that the turnover of the secretion of thyrotrophs may be very quick without the storage phase. If thyrotrophs really achieve this secretory mechanism, it is a natural result that evidence of the elaborated function of thyrotrophs has not been secured in our electron microscopy.

Rosa and D'Angelo (1972) divided intact thyrotrophs into two types, storage and secretory. The former is of polyhedral shape containing numerous small granules $150 \mathrm{~m} \mu$ in maximal diameter, while the latter is a hyperactive vesiculated round cell characterized by the dense arrangement of dilated cisternae. The granules were sparsely distributed in the storage type of thyrotrophs. Rosa and D'Angelo concluded that TX-cells originated from the vesiculated round thyrotrophs of storage type. However, the absence of transitional pictures between the two types of thyrotrophs seems to have hindered an establishment of their theory on the genesis of TX-cells. It seems to us that the vesiculated round thyrotrophs described by Rosa and D'Angelo may resemble gonadotrophs. If so, their thyrotrophs may be synonymous with gonadotrophs. It is generally believed that the secretory cycle of thyrotrophs has not been determined. The enlargement of the Golgiring in the adenohypophyseal cells has been regarded by many investigators as an indicator of elaboration of their synthesizing function. Such enlargement was not, however, found in 
any thyrotrophs in the present observation. Therefore, thyrotrophs do not respond to thyroidectomy as definitely as gonadotrophs do to gonadectomy.

From their two histological observations that the old gonadotrophs were degenerated in the initial phase of thyroidectomy and that TX-cells with the prominent Golgi-ring gradually transformed into signet-ring cells like castration cells, Yoshimura and Ishikawa (1969) thought that TX-cells originated from the intermediate cells between chromophobes and basophils, but they did not provide evidence that TX-cells were made from genuine thyrotrophs. As the epithelium of seminal vesicles significantly increased in height in the chronic phase of thyroidectomy, these authors conceived that a large amount of GTH might be secreted, and came to assume the activation of gonadotrophic potency of some fully developed TX-cells. However, the exact distinction of TX-cells from the resembling gonadotrophs was almost impossible to make by the present light microscopical observations on epon sections. But both cells could be easily distincted from each other on the electron micrographs because of their respective fine structural features mentioned above. The fact that numerous immature gonadotrophs came into being in the later phase was elicited for the first time by the present observation, and furnished a hint as to the interpretation of possible elaboration of gonadotrophic function.

Our speculation that TX-cells may originate acidophils must be reasonable, because the possible entire course of transformation from degranulated acidophils to TX-cells was successfully demonstrated in this study. From the interphase to the later phase the whole pituitary was occupied by the vesiculated TXcells. The population of the original sources of TX-cells was roughly estimated: Percentages of the cells along the acidophil-axis might be more than $50 \%$, and those of the cells along the basophil-axis about $20 \%$.

Previously, histochemical evidence was ad- duced by Purves and Griesbach (1956) that no appreciable amount of TSH was contained in the large TX-cells of chronically hypothyroid rats. The hormonal activity of TX-cells was recently investigated by Baker and $\mathrm{Yu}$ (1971) with the immunochemical technique using the anti-TSH. They did not find the TSH, $\mathrm{GH}$, prolactin, $\mathrm{LH}$ and ACTH activities in TXcells. Nevertheless, morphologically TX-cells contained a number of small granules in their ground matrix. We, therefore, should like to assume that these granules in TX-cells are identical with those of small size $(130 \mathrm{~m} \mu$ in diameter) remaining in acidophils after thyroidectomy. The hormonal activity of separated small granules collected from the pellets of isolated acidophils from normal rats was examined by Ishikawa et al. (1972) who successfully demonstrated an ACTH activity within these granules. The small granules in TX-cells could not always be regarded as $\beta$-granules of TSH carriers, but they were rightly regarded, in many cases, as ACTH carriers. It was suggested that there might be two kinds of TX-cells with or without Tgranules in their cisternae. Such suggestion seems to facilitate an explanation that TX-cells develop from their prescursor cells, either along the acidophil- or basophil-axis.

Our present data coincided, in some respects, with the finding of Dineman (1969), who concluded that TX-cells independently originated from LH-, LTH- and GH-cells due to his quantitative estimation of various cell types. Recently Stratmann et al. (1972) injected tritiated thymidine into rats given methylthiouracil (PTU), in which the nuclei of their pituitary somatotrophs had been labeled and the nuclei of their thyrotrophs were labeled after the treatment. Their radioautography was contradictory to the transformation of somatotrophs into TX-cells, and indicated that TX-cells were derived only from thyrotrophs through mitosis. However, there may still be some difficulties in the experimental design and evaluation of the results. The acidophil theory as to the genesis 
of TX-cells seems to have been firmly established by the present investigation. In the next paper, we shall report our experimental results concerning the reversion of TX-cells into their original acidophils.

\section{References}

Applington, H. W. Jr. (1962). Anat. Rec. 143, 133.

Baker, B. L. and Ya-Yen Yu (1971). Endocrinology 89, 996.

Contopoulos, A. N., M. E. Simpson and A. A. Koneff (1958). Endocrinology 63, 642.

D'Angelo, S. A. (1963). Thyrotropin, p. 80 Ed. by S. C. Werner, Thomas, Springfield, Illinois.

Dent, J. N. (1961). Gen. Comp. Endocrin. $1,218$.

Dhom, G. and H. U. Tietze (1962). Endokrinologie 42, 284.

Dingeman, P. K. (1969). J. Ultrastr. Res. 26, 480.

Elftman, H. (1958). Anat. Rec. 131, 119.

Goluboff, L. G., M. E. MacRae, C. Ezrin and E. A. Sellers (1970). Endocrinology 87, 1113.

Harumiya, K. (1972). Endocrinol. Japon. 19, 461.

Imai, Y., A. Sue and A. Yamaguchi (1968). J. Electron Micros. 17, 84.

Ishikawa, H. (1969). Endocrinol. Japon. 16, 517.

Ishikawa, H., Y. Ohtsuka, F. Soyama and F. Yoshimura (1972). Ibid. 19, 215.

Mastro, A., W. C. Heymer and C. D. Therrick (1969a). Exp. Cell Res. 54, 407.

Mastro, A., E. Skelton and W. C. Heymer (1969b). J. Cell Biol. 43, 626.

Mess, B. (1958). Endokrinologie 35, 296.

Messier, B. (1965). Anat. Rec. 153, 343.

Messier, B. (1966). Acta Endocrin. 52, 391.

Millonig, G. (1961). J. Biophys. Biochem. Cytol. 9, 409.

Nakane, P.K. (1971). Progr. in Brain Research, Vol. 34, Histochemistry of Nervous Transmission. edit. by Erankö P.139, Amsterdam.

Panda, J. N. and C. W. Turner (1967). Acta Endocrin. 54, 485.

Paget, G. E. and E. Eccleston (1959). Stain Technol. 34, 223.

Payne S. F. (1957). J. Morphol. 101, 89.

Peter, B. H. and N. S. Halmi (1961). Endocrinology 68, 844.

Purves, H. D. and W. E. Griesbach (1956). J. Endocrin. 13, 365.

Regynalds, E. S. (1963). J. Cell Biol. 17, 208.

Rosa, C. C. and S. A. D'Angelo (1972). Am. J. Anat. 135, 33.

Saki, J. (1962). Med. J. Osaka Univ. 12, 233.

Salamon D. F. (1964). J. Endocrin. 29, 283.

Stratmann, I., C. Ezrin, E. A. Sellers and G. T. Simon (1972). Endocrinology 90, 728.

Ueda, G. and J. Mori (1968). Am. J. Pathol. $\mathbf{5 1}, 601$.

Yokoyama, M. (1972). Endocrinol. Japon. 19, 533.

Yoshimura, F. and H. Ishikawa (1969). Ibid. 16, 69.

Yoshimura F., K. Harumiya, H. Ishikawa and Y. Ohtsuka (1969). Ibid. 16, 531.

Yoshimura, F., K. Harumiya and H. Kiyama (1970). Arch. Histol. Jap. 31, 333. 